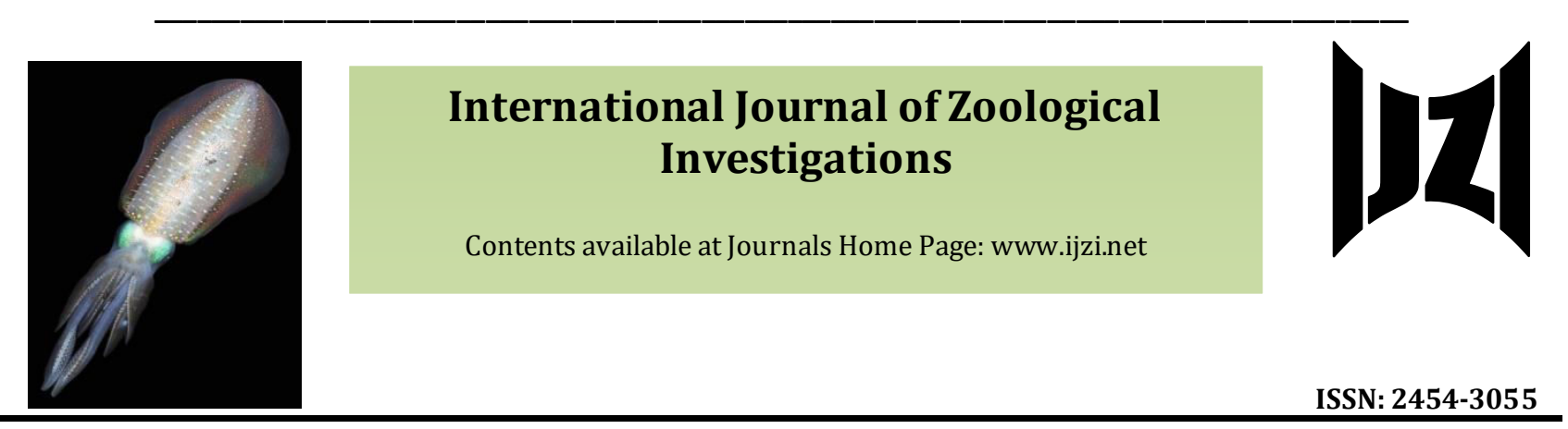

\title{
Effect of Euphorbia royleana on Growing Stages of Freshwater Fish Channa punctatus
}

\author{
Singh Jaya1, Singh Digvijay ${ }^{2 *}$ and Singh Ajay ${ }^{1}$ \\ 1Department of Zoology, DDU Gorakhpur University, Gorakhpur - 273009 (U. P.), India \\ 2Department of Zoology, Government Degree College, Sehmo, Basti (U. P.), India \\ *Corresponding Author
}

Received: $13^{\text {th }}$ May, 2021

Accepted: $4^{\text {th }}$ June, 2021

Published online: $7^{\text {th }}$ June, 2021

https://doi.org/10.33745/ijzi.2021.v07i01.024

\begin{abstract}
In this study toxicity of Euphorbia royleana latex and stem bark extract was evaluated in a static bioassay test for the fry and fingerlings of freshwater fish Channa punctatus. For fry the $\mathrm{LC}_{50}$ values for Euphorbia royleana latex were 12.66, 6.27, 4.04 and $3.05 \mathrm{mg} / \mathrm{L}$ whereas for stem bark extract the $\mathrm{LC}_{50}$ values were 113.77, 89.16, 71.99 and $56.59 \mathrm{mg} / \mathrm{L}$ for $24,48,72$ and $96 \mathrm{~h}$, respectively. It seems that toxicity of latex was more pronounced as compared to stem bark extract. The $\mathrm{LC}_{50}$ values for latex for fingerlings were $22.58,18.14,14.99$ and $12.34 \mathrm{mg} / \mathrm{L}$ whereas for stem bark extract the $\mathrm{LC}_{50}$ values were $614.35,585.06,535.93$ and $475.37 \mathrm{mg} / \mathrm{L}$ for $24,48,72$ and $96 \mathrm{~h}$, respectively. The activities of the latex and stem bark extract were time- and dose-dependant. The present study clearly indicates that Euphorbia royleana extracts should be applied with great precautions nearby the aquatic reservoirs as it is toxic to growing stages of the fish.
\end{abstract}

Keywords: Euphorbia royleana, Channa punctatus, Mortality, Toxicity, $\mathrm{LC}_{50}$

Citation: Singh Jaya, Singh Digvijay and Singh Ajay: Effect of Euphorbia royleana on growing stages of freshwater fish Channa punctatus. Intern. J. Zool. Invest. 7 (1): 294-300, 2021.

https://doi.org/10.33745/ijzi.2021.v07i01.024

\section{Introduction}

Medicinal plants have been widely used in India to treat various disorders, including infectious diseases. Indeed, important diseases, such as epizootic ulcerative syndrome, myxobolasis, gyrodactylosis and argulosis have been successfully controlled using turmeric, garlic, onion and other herbal materials (Dey et al., 1997; Malik et al., 2018). In recent years, various medicinal plants have been used in aquaculture as molluscicides and piscicides for the removal of unwanted aquatic organism (Rug and Ruppel, 2000; Yadav and Singh, 2002; Tiwari et al., 2005; Singh et al., 2009; Kaur et al., 2016; 
Singh and Singh, 2020).

Natural products have gained greater importance, since it is believed that the natural compounds are ecologically sound and culturally more acceptable. Several plants, such as Euphorbia royleana, possess bioactive chemical constituents that have high pesticidal activity, making this plant useful for controlling predatory fish, disease causing insects and freshwater snails in the water bodies (Okunji and Iwu, 1988; Gopalsamy et al., 1990; Alard et al., 1991; Singh et al., 1996; Singh and Singh, 2003; Singh et al., 2009; Prasad et al., 2010, 2016, 2017; Kaur and Gill, 2014). Yet, the eco-toxic properties of these plant materials on non-target animals sharing the habitat with target animals have not been investigated.

We are interested in eco-toxic properties of plant origin pesticides. This study examined the toxicity of Euphorbia royleana latex and stem-bark extracts against fry and fingerlings of freshwater fish Channa punctatus. Euphorbia royleana is a plant used in fish catching practices (Prakash and Singh, 2000, Ahmad, 2016; Singh et al, 2017). C. punctatus, is an important fish of Indian fisheries and a good experimental animal due to its size, easy availability and good survival in laboratory.

\section{Materials and Methods}

Physico-chemical characteristics of water:

Water containing the fish had a pH 7.3 to 7.5, dissolved oxygen of 6.9 to $7.7 \mu \mathrm{l} / \mathrm{L}$, free carbon dioxide of 4.5 to $6.5 \mu \mathrm{l} / \mathrm{L}$ and bicarbonate alkalinity of 105.0 to $109.0 \mathrm{mg} / \mathrm{L}$ as measured according to methods of APHA et al. (1998). Atmospheric and water temperature ranged from 29.5 to $30.5 \mathrm{C}$ and from 28.0 to $29.0 \mathrm{C}$, respectively.
The Test animal:

Fry $(2.1-3.2 \mathrm{~cm})$ and fingerlings $(4.2-6.7 \mathrm{~cm})$ of the fish Channa punctatus were collected from Ramgarh Lake, Gorakhpur, India. After collection they were stored in glass aquaria containing $50 \mathrm{~L}$ de-chlorinated tap water for acclimatization for 7 days to laboratory conditions. Dead fish were removed as soon as possible to prevent the fouling of the aquarium media. Water was changed every 24 h. Average size of growing stages of the fish were used for the experiment.

Preparation of extract:

The latex and stem-bark extract of Euphorbia royleana (collected from plants growing locally in their natural habitats) were used in this study. The latex, collected by draining into a glass tube after cutting the stem apex, was lyophilized at $-40 \mathrm{C}$ and the dried powder was used in experiments. The collected stem-bark was dried overnight at $38 \mathrm{C}$ and then pulverized in a mortar and pestle for use in the experiments. Dried powder of each plant sample was mixed with appropriate volumes of distilled water to obtain desired concentration.

Treatment protocol for dose-response relation:

Toxicity experiments were performed by the method of Singh and Agarwal (1988). For each experimental, ten fry and fingerlings were placed separately in a glass aquarium containing $6 \mathrm{~L}$ of de-chlorinated tap water. The fry and fingerlings were exposed to four concentrations of the extracts for $96 \mathrm{~h}$. Separate aquaria, matched with each treatment, but containing no extract, were kept in similar conditions as controls. Mortality was recorded at $24 \mathrm{~h}, 48 \mathrm{~h}, 72 \mathrm{~h}$ and $96 \mathrm{~h}$. Fry and fingerlings were considered 
dead if they failed to respond to prodding with glass rod. Dead fish were removed from the test container to prevent water fouling. LC values, upper and lower confidence limits and slope value, ' $g$ ' values and heterogeneity factor were calculated according to the methods of Russel et al. (1977).

\section{Results}

Investigations on the toxicity of latex and stem-bark extracts of Euphorbia royleana against the fry and fingerlings of freshwater paddy fish C. punctatus showed that latex was more toxic than the stem-bark extract (Tables 1-4). For fry the $\mathrm{LC}_{50}$ values for Euphorbia royleana latex were 12.66, 6.27, 4.04 and 3.05 $\mathrm{mg} / \mathrm{L}$ (Table 1) whereas for stem bark extract the $\mathrm{LC}_{50}$ values were $113.77,89.16,71.99$ and $56.59 \mathrm{mg} / \mathrm{L}$ (Table 2) for 24, 48, 72 and $96 \mathrm{~h}$, respectively. It seems that toxicity of latex was more pronounced as compared to stem bark extract. The $\mathrm{LC}_{50}$ values for latex for fingerlings were 22.58, 18.14, 14.99 and 12.34 $\mathrm{mg} / \mathrm{L}$ (Table 3) whereas for stem bark extract the $\mathrm{LC}_{50}$ values were $614.35,585.06,535.93$ and $475.37 \mathrm{mg} / \mathrm{L}$ (Table 4) for 24, 48, 72 and $96 \mathrm{~h}$, respectively.

In case of both the extracts, the $\mathrm{LC}_{50}$ values were time- and dose-dependent. A decrease in the dose necessary to produce the response occurred with an increase in exposure time-for fry the $\mathrm{LC}_{50}$ for latex decreased from 12.66 to $3.05 \mathrm{mg} / \mathrm{L}$ when the exposure period was increased from $24 \mathrm{~h}$ to $96 \mathrm{~h}$.

A value of the ' $t$ ' ratio greater than 1.96 (indicating a significant regression) and the heterogeneity values of less than 1.0 denoting that in the replicate tests of random samples, the concentration response lines would fall within 95 per cent confidence limits and thus model $t$-data adequately. The index of significance of potency examination of ' $\mathrm{g}$ ' indicates that the value of the mean was within limits at all probability levels.

\section{Discussion}

The present study demonstrated that both the latex and the stem-bark extract of E. royleana were lethal to C. punctatus at both stages of fish growth. The latex, however, was more toxic than the stem-bark extract. The lethality of a given concentration of the latex and stembark extracts to fish increased with exposure time.

The most obvious sign of distress in the fish treated with latex or extract was restlessness, labored breathing, loss of equilibrium and lethargy. Other altered behaviour noticed was frequent surfacing, muscular tetany and jumping from the water. The progressive toxic effects of the latex and stem-bark extract caused the fry and fingerlings to sink to bottom of the aquaria and usually lead to death. Singh and Agarwal $(1984,1990)$ have reported earlier that latex of E. royleana and Jatropha gosspyfolia cause inhibition of acetylcholine esterase and reduce the endogenous level of other known neurotransmitters (5-hydroxytrytamine, epinephrine and dopamine) in nervous tissues of the freshwater snail Lymnaea acuminata and fish Channa marulius in the time- and dosedependent manner.

Similar behavioural responses have been observed in fish exposed to organophosphate and carbamate pesticides (Ahmad, 1975; Verma et al., 1978; Ghosh, 1986; Gill et al., 1991; Singh et al, 2004). These compounds, which are cholinergic inhibitors, are known nerve poisons (Stansely, 1993). Gill et al. (1991), Singh (2001) and Singh et al. (2020) described that the behavioural anomalies are 
Table 1: Toxicity of latex extracts of E. royleana to fry of the fish C. punctatus

\begin{tabular}{|c|c|c|c|c|c|c|}
\hline $\begin{array}{c}\text { Exposure } \\
\text { period }\end{array}$ & Parameter & $\begin{array}{c}\text { Limits } \\
\text { Upper - lower }[\mathrm{mg} / \mathrm{L}]\end{array}$ & Slope value & 'g' value & $\begin{array}{c}t ' \\
\text { value }\end{array}$ & $\begin{array}{l}\text { Hetero- } \\
\text { geneity }\end{array}$ \\
\hline \multirow{3}{*}{$24 \mathrm{~h}$} & $\mathrm{LC}_{10}=3.48$ & $1.92-4.43$ & \multirow{3}{*}{$2.28 \pm 0.56$} & \multirow{3}{*}{0.24} & \multirow{3}{*}{4.03} & \multirow{3}{*}{0.22} \\
\hline & $\mathrm{LC}_{50}=12.66$ & $9.54-26.28$ & & & & \\
\hline & $\mathrm{LC}_{90}=46.07$ & $23.42-35.14$ & & & & \\
\hline \multirow{3}{*}{$48 \mathrm{~h}$} & $\mathrm{LC}_{10}=1.93$ & $0.96-2.67$ & \multirow{3}{*}{$2.5 \pm 0.49$} & \multirow{3}{*}{0.15} & \multirow{3}{*}{5.10} & \multirow{3}{*}{0.24} \\
\hline & $\mathrm{LC}_{50}=6.27$ & $5.34-7.55$ & & & & \\
\hline & $\mathrm{LC}_{90}=20.40$ & $14.0-46.16$ & & & & \\
\hline \multirow{3}{*}{$72 \mathrm{~h}$} & $\mathrm{LC}_{10}=1.60$ & $0.92-2.19$ & \multirow{3}{*}{$3.19 \pm 0.51$} & \multirow{3}{*}{0.09} & \multirow{3}{*}{6.32} & \multirow{3}{*}{0.15} \\
\hline & $\mathrm{LC}_{50}=4.04$ & $3.51-4.60$ & & & & \\
\hline & $\mathrm{LC}_{90}=10.19$ & $8.41-14.21$ & & & & \\
\hline \multirow{3}{*}{$96 \mathrm{~h}$} & $\mathrm{LC}_{10}=1.29$ & $0.69-1.81$ & \multirow{3}{*}{$3.44 \pm 0.56$} & \multirow{3}{*}{0.10} & \multirow{3}{*}{6.13} & \multirow{3}{*}{0.33} \\
\hline & $\mathrm{LC}_{50}=3.05$ & $2.35-3.57$ & & & & \\
\hline & $\mathrm{LC}_{90}=7.12$ & $6.18-9.17$ & & & & \\
\hline
\end{tabular}

- Batches of 10 fish were exposed to four different concentrations of E. royleana latex.

- Mortality was determined every $24 \mathrm{~h}$. Each set of experiment was replicated six times.

- Concentrations given are the final concentration $(\mathrm{w} / \mathrm{v})$ in the aquarium water.

- Regression coefficient showed that there was significant $(\mathrm{P}<0.05)$ negative correlation between exposure period and different LC values.

Table 2: Toxicity of stem-bark extracts of E. royleana to fry of the fish C. punctatus

\begin{tabular}{|c|c|c|c|c|c|c|}
\hline $\begin{array}{c}\text { Exposure } \\
\text { period }\end{array}$ & Parameter & \begin{tabular}{|c|} 
Limits \\
Upper - lower $[\mathrm{mg} / \mathrm{L}]$
\end{tabular} & Slope value & 'g' value & $\begin{array}{c}\text { 't' } \\
\text { value }\end{array}$ & $\begin{array}{l}\text { Hetero- } \\
\text { geneity }\end{array}$ \\
\hline \multirow{3}{*}{$24 \mathrm{~h}$} & $\mathrm{LC}_{10}=41.18$ & $23.71-52.67$ & \multirow{3}{*}{$2.91 \pm 0.61$} & \multirow{3}{*}{0.17} & \multirow{3}{*}{4.75} & \multirow{3}{*}{0.15} \\
\hline & $\mathrm{LC}_{50}=113.77$ & $98.61-146.54$ & & & & \\
\hline & $\mathrm{LC}_{90}=314.34$ & $212.47-787.18$ & & & & \\
\hline \multirow{3}{*}{$48 \mathrm{~h}$} & $\mathrm{LC}_{10}=34.74$ & $20.14-45.16$ & \multirow{3}{*}{$3.13 \pm 0.59$} & \multirow{3}{*}{0.14} & \multirow{3}{*}{5.30} & \multirow{3}{*}{0.48} \\
\hline & $\mathrm{LC}_{50}=89.16$ & $78.73-102.59$ & & & & \\
\hline & $\mathrm{LC}_{90}=228.84$ & $171.65-417.79$ & & & & \\
\hline \multirow{3}{*}{$72 \mathrm{~h}$} & $\mathrm{LC}_{10}=29.83$ & $17.23-39.36$ & \multirow{3}{*}{$3.35 \pm 0.58$} & \multirow{3}{*}{0.12} & \multirow{3}{*}{5.69} & \multirow{3}{*}{0.60} \\
\hline & $\mathrm{LC}_{50}=71.99$ & $61.98-80.77$ & & & & \\
\hline & $\mathrm{LC}_{90}=173.79$ & $139.93-264.02$ & & & & \\
\hline \multirow{3}{*}{$96 \mathrm{~h}$} & $\mathrm{LC}_{10}=23.53$ & $12.09-32.69$ & \multirow{3}{*}{$3.36 \pm 0.60$} & \multirow{3}{*}{0.13} & \multirow{3}{*}{5.59} & \multirow{3}{*}{0.52} \\
\hline & $\mathrm{LC}_{50}=56.59$ & $45.04-64.89$ & & & & \\
\hline & $\mathrm{LC}_{90}=136.11$ & $114.48-189.48$ & & & & \\
\hline
\end{tabular}

- Batches of 10 fish were exposed to four different concentrations of E. royleana stem bark.

- Mortality was determined every $24 \mathrm{~h}$. Each set of experiment was replicated six times.

- Concentrations given are the final concentration $(w / v)$ in the aquarium water.

- Regression coefficient showed that there was significant $(\mathrm{P}<0.05)$ negative correlation between exposure period and different LC values. 
Table 3: Toxicity of latex extracts of E. royleana to fingerlings of fish C. punctatus

\begin{tabular}{|c|c|c|c|c|c|c|}
\hline \multirow[t]{2}{*}{$\begin{array}{l}\text { Exposure } \\
\text { period }\end{array}$} & \multirow{2}{*}{ Parameter } & Limits & \multirow[t]{2}{*}{ Slope value } & \multirow[t]{2}{*}{$\begin{array}{c}\text { 't' } \\
\text { value }\end{array}$} & \multirow[t]{2}{*}{ 'g' value } & \multirow[t]{2}{*}{$\begin{array}{l}\text { Hetero } \\
\text { geneity }\end{array}$} \\
\hline & & Upper - lower [mg/L] & & & & \\
\hline \multirow{3}{*}{$24 \mathrm{~h}$} & $\mathrm{LC}_{10}=8.96$ & $5.25-11.25$ & \multirow{3}{*}{$3.19 \pm 0.71$} & \multirow{3}{*}{4.53} & \multirow{3}{*}{0.18} & \multirow{3}{*}{0.27} \\
\hline & $\mathrm{LC}_{50}=22.58$ & $19.79-28.90$ & & & & \\
\hline & $\mathrm{LC}_{90}=65.86$ & $39.32-141.03$ & & & & \\
\hline \multirow{3}{*}{$48 \mathrm{~h}$} & $\mathrm{LC}_{10}=7.53$ & $4.20-9.73$ & \multirow{3}{*}{$3.54 \pm 0.69$} & \multirow{3}{*}{4.82} & \multirow{3}{*}{0.17} & \multirow{3}{*}{0.72} \\
\hline & $\mathrm{LC}_{50}=18.14$ & $16.17-20.80$ & & & & \\
\hline & $\mathrm{LC}_{90}=43.73$ & $32.84-84.316$ & & & & \\
\hline \multirow{3}{*}{$72 \mathrm{~h}$} & $\mathrm{LC}_{10}=6.88$ & $4.00-8.89$ & \multirow{3}{*}{$3.78 \pm 0.72$} & \multirow{3}{*}{5.26} & \multirow{3}{*}{0.14} & \multirow{3}{*}{0.80} \\
\hline & $\mathrm{LC}_{50}=14.99$ & $13.10-16.60$ & & & & \\
\hline & $\mathrm{LC}_{90}=32.69$ & $26.72-49.65$ & & & & \\
\hline \multirow{3}{*}{$96 \mathrm{~h}$} & $\mathrm{LC}_{10}=6.16$ & $3.51-8.05$ & \multirow{3}{*}{$4.24 \pm 0.78$} & \multirow{3}{*}{5.37} & \multirow{3}{*}{013} & \multirow{3}{*}{0.74} \\
\hline & $\mathrm{LC}_{50}=12.34$ & $10.12-13.78$ & & & & \\
\hline & $\mathrm{LC}_{90}=24.72$ & $21.45-32.54$ & & & & \\
\hline
\end{tabular}

- Batches of 10 fish were exposed to four different concentrations of E. royleana latex.

- Mortality was determined every 24h. Each set of experiment was replicated six times.

- Concentrations given are the final concentration $(w / v)$ in the aquarium water.

- Regression coefficient showed that there was significant $(\mathrm{P}<0.05)$ negative correlation between exposure period and different LC values.

Table 4: Toxicity of stem-bark extracts of E. royleana to fingerlings of fish C. punctatus

\begin{tabular}{|c|c|c|c|c|c|c|}
\hline \multirow[t]{2}{*}{$\begin{array}{c}\text { Exposure } \\
\text { period }\end{array}$} & \multirow{2}{*}{ Parameter } & Limits & \multirow[t]{2}{*}{ Slope value } & \multirow[t]{2}{*}{ 'g'value } & \multirow[t]{2}{*}{$\begin{array}{c}\text { ' } t \text { ' } \\
\text { value }\end{array}$} & \multirow[t]{2}{*}{$\begin{array}{l}\text { Hetero- } \\
\text { geneity }\end{array}$} \\
\hline & & Upper - lower [mg/L] & & & & \\
\hline \multirow{3}{*}{$24 \mathrm{~h}$} & $\mathrm{LC}_{10}=396.53$ & $260.67-417.09$ & \multirow{3}{*}{$5.48 \pm 1.05$} & \multirow{3}{*}{0.14} & \multirow{3}{*}{4.73} & \multirow{3}{*}{0.53} \\
\hline & $\mathrm{LC}_{50}=614.35$ & $572.31-666.03$ & & & & \\
\hline & $\mathrm{LC}_{90}=1052.55$ & $891.22-1499.54$ & & & & \\
\hline \multirow{3}{*}{$48 \mathrm{~h}$} & $\mathrm{LC}_{10}=358.58$ & $289.57-455.82$ & \multirow{3}{*}{$5.12 \pm 1.08$} & \multirow{3}{*}{0.17} & \multirow{3}{*}{5.20} & \multirow{3}{*}{0.17} \\
\hline & $\mathrm{LC}_{50}=585.06$ & $650.12-814.82$ & & & & \\
\hline & $\mathrm{LC}_{90}=1253.67$ & $1003.27-2119.08$ & & & & \\
\hline \multirow{3}{*}{$72 \mathrm{~h}$} & $\mathrm{LC}_{10}=312.88$ & $213.28-374.66$ & \multirow{3}{*}{$5.48 \pm 1.04$} & \multirow{3}{*}{0.14} & \multirow{3}{*}{5.24} & \multirow{3}{*}{0.60} \\
\hline & $\mathrm{LC}_{50}=535.93$ & $485.86-574.77$ & & & & \\
\hline & $\mathrm{LC}_{90}=917.98$ & $800.60-1219.03$ & & & & \\
\hline \multirow{3}{*}{$96 \mathrm{~h}$} & $\mathrm{LC}_{10}=289.26$ & $195.69-349.50$ & \multirow{3}{*}{$5.94 \pm 1.08$} & \multirow{3}{*}{0.13} & \multirow{3}{*}{5.45} & \multirow{3}{*}{0.59} \\
\hline & $\mathrm{LC}_{50}=475.37$ & $416.47-513.76$ & & & & \\
\hline & $\mathrm{LC}_{90}=781.22$ & 705.89-948.278 & & & & \\
\hline
\end{tabular}

- Batches of 10 fish were exposed to four different concentrations of E. royleana latex.

- Mortality was determined every 24h. Each set of experiment was replicated six times.

- Concentrations given are the final concentration $(w / v)$ in the aquarium water.

- Regression coefficient showed that there was significant $(\mathrm{P}<0.05)$ negative correlation between exposure period and different LC values. 
due to inhibition of cholinergic impulses by the hydrolysis of neurotransmitter acetylcholine released during synaptic transmission. Similar anticholinergic activity may be responsible for behavioural changes observed with the growing stages of fish exposed to the plant latex and stem-bark extract.

Increase of mortality with increased exposure time could be due to several factors acting separately or conjointly. For example, uptake of pesticides is time dependent, leading to a progressive increase of pesticides in the animal body. Stability of pesticide in an environment and the rate of detoxification by the animal can also affect relationship between mortality and exposure period (Kaur and Garg, 2014). Kinghorn and Evans (1975) demonstrated that the toxicological action in many plants of euphorbiales is due to presence of a group of diterphene phorbal esters, while in plants of the family euphorbiaceae, the alkaloids, sterols and triterpenoids are responsible for toxicity (Wealth of India., 1995). Singh et al. (2003) and Malik (2018) have shown, however, that sub-lethal doses of extract increase lipid peroxidation and causes reduction in the levels of phospholipids in the nervous tissues of freshwater animals. The latex was more toxic than the stem-bark extract and the lethality of a given concentration of latex and extract to fish increase with exposure time.

\section{Conclusion}

Finding in this study indicate that E. royleana has potent piscicidal activity and can achieve high kill rates if a similar relationship of lethality to dose occurs under field conditions as observed in this study. Thus, plant extracts used directly in water bodies may have unexpected long-term effects on non-target organisms.

\section{References}

Ahmad AM. (1975) Acute toxicity of four organophosphorus insecticides to a freshwater teleost Channa punctatus (Bloch). Pakistan J Zool. 7: 135-160.

Ahmand A. (2016) Environmental ethics and sustainable development: Some reflection in contemporary context. One day seminar on "Law and Ethics in public domain: Contemporary issues and challenges in India" dated 23 November 2016 organised by Department of Law, BBA University, Lucknow with Sociomers Foundation, Lucknow.

Alard F, Freets Sand Triest ETL. (1991) Toxicite 'D' Ambrosia maritime molluscicides, sur less organism aquatiques Non-cibles. Toxicon 29: 745-750.

APHA/ WWA/ WEF. (1998) Standard methods for the analysis of water and wastewater (20 th ed.) APHA 1015, Fifteen Street, NW Washington DC 20005- 26005.

Dey RK, Mohanthy AN and Chandra S. (1998) Effect of turmeric in combination with lime on the water quality parameters of fish pods. J Aquacul. 5: 83-87.

Ghosh TK. (1986) Comparative toxicogenic evaluation of two commonly used organophosphorus pesticides, Ekalux (EC 25) and Rogar (Dimethoate) on the ovarian recrudescence in the freshwater teleost Sarotherodon mossambicus. Utter Pradesh J Zool. 6: 21.

Gill TS, Pandey J and Tewari H. (1991) Individual and combined toxicity of common pesticides to teleost, Puntius conchonius (Ham). Ind J Exp Biol. 29: 145-148.

Gopalsamy N, Guheo H, Owdally R. Hostettaman K (1990) Molluscicidal saponins of Polysacias dechrostachya. Phyochem. 29: 793-795.

Kaur HG and Garg H. (2014) Pesticides: Environmental impact and Management strategies. DOI: $10.5772 / 57399$.

Kaur N, Singh DK and Singh VK. (2016) Evaluation of Chlorophyllin bait on acetylcholinesterase and cytochrome oxidase activities in nervous tissues of Lymnaea acuminata with exposure to sunlight and red light. Eur J Biol Res. 6: 254-259.

Kinghorn AD and Evans F.J. (1975) A biological screen of selected species of the genus Euphorbia for skin irritant effects. Planta Medica 28: 325 -335. 
Malik A and Grohmann, E. and Akthar R. (2018) Environmental deterioration and human health. Springer Publisher (ISBN: 978-94-007-7890-0) pp. 99-123.

Okunji CO and Iwu MM. (1988) Control of schistosomiasis using hegerian medicinal plants as molluscicides. Intern J Crude Drug Res. 26: $246-252$.

Prakash A and Singh KK. (2000) Observation on some high valued ethno medicinal plants among the tribal of Uttar Pradesh. J Med Arom Plants 22/4A-23/1: 148-163.

Prasad M, Kumar A, Mishra D, Srivastav SK, Srivastav Ajai K. (2010) Acute toxicity of Euphorbia royleana boiss (euphorbiaceae) latex on fresh water catfish, Heteropneustes fossilis (Siluriformes, Heteropneustidae). Acta Toxicol Argent.18: 5-9.

Prasad M, Kumar A, Srivastav SK and Srivastav Ajai k. (2016) Response of prolactin cells of stinging catfish, Heteropneustes fossilis to Euphorbia royleana treatment. Inter J Fish Aquat Sci. 4: 330-334.

Prasad M, Kumar A, Srivastav SK and Srivastav Ajai k. (2017) Alterations in the corpuscles of Stannius of Euphorbia royleana treated catfish, Heteropneustes fossilis.Iranian J Toxicol. 11: 27-32.

Rug M andRuppel A. (2000) Toxic activities of the plant Jatropha curcas against intermediate snail hosts and larvae of schistosomia. Trop Med Internat Hlth. 5: 423-430.

Russel RM, Robertson JL and Savin NE. (1977) POLO: a new computer programme for probit analysis. Bull Entomol Soc Am. 23: 209-213.

Singh A and Agarwal RA. (1988) Possibility of using latex of euphorbiales for snail control. Sci Total Environ. 77: 231-236.

Singh A and Agarwal RA. (1990) Molluscicidal and anticholinesterase activity of euphorbiales. Biol Agricult Horticult. 7: 81-91.

Singh A, Singh DK, Mishra TN, Agarwal RA. (1996) Molluscicides of plant origin. Biol Agricul Horticul. 13: 205-252.

Singh D. (2001) Studies on toxicological and biochemical effect of phytopesticides on freshwater non-target fish Channa punctatus. Ph.D. Thesis submitted to DDU Gorakhpur University, Gorakhpur UP, India.
Singh D and Singh A. (2003) Effect of stem-bark extract of some common plants on non-target freshwater fish Channa marulius (Ham). Ind J Fish. 50: 525-532.

Singh D, Yadav RP and Singh A. (2003) Changes in phospholipids and lipid peroxidation level due to Codiaeum variegatum latex in snail Lymnaea acuminata. National Symposium on BSHEA at Dayalbagh Educational Institute, Agra dated 2-4th Oct. 2003 pp- 269-273.

Singh DK and Agarwal RA. (1984) Correlation of the anticholinesterase and molluscicidal activity of latex of E. royleana. J Nat Prod. 47: 702-705.

Singh J, Singh D and Singh A. (2009) Toxicity of Euphorbia royleana and Nerium indicum leaf extracts to freshwater fish Channa marulius. J Nat Resour Develop. 4 (1): 1 - 5.

Singh K and Singh VK. (2020) Evaluation of effect of pheophorbide on reproduction and biochemical changes of freshwater snail Lymnaea acuminata. Asian J Adv Res. 4(2): 1-10.

Singh SK, Tripathi PK, Yadav RP, Singh D and Singh A. (2004) Toxicity of malathion and carbaryl pesticides: Effects on some biochemical profiles of the freshwater fish Colisa fasciatus. Bull Environ Contam Toxicol. 72(3): 592-599

Stansely W. (1993) Field result using cholinesterase reactivation techniques to diagnose acute anticholinesterase poisoning in birds and fish. Arch Environ Contam Toxicol. 42: 643-650.

Tiwari S, Singh SK and Singh A. (2005) The contribution of the anti-cholinesterase activity of Pediclanthus lithymaloide to its molluscicidal activity. African J Trad Complem Altern Med.2 (3): 326-336.

Verma SR, Bhatnagar MC and Dalela, RC. (1978) Biocides in relation to water pollution. Part II, Bioassay studies of new biocides to freshwater fish Channa gachua. Acta Hydrochim Hydrobiol. 6: 137-144.

Wealth of India (1995) A dictionary of Indian raw material and industrial products. Publications and Information Directorate, CSIR New Delhi Vol. X: sp-w.

Yadav RP and Singh A. (2002) Toxic effect of latex of Croton tiglium on Lymnaea acuminata and Channa punctatus. Iberus 20 (2): 31-44. 